\title{
Restitution of the ACL's Physiometry: The Role of Deviation of ACL's New Insertion
}

\author{
*Khalifa Elmajri \\ Hopital Psychiatrique De La Croix, France \\ Submission: December 11, 2016; Published: January 06, 2017 \\ *Corresponding author: Khalifa Elmajri, Msc Biomechanics, Fellow center Albert Trillat, Hôpital de la Croix-Rousse 103 Grande Rue de la Croix- \\ Rousse, 69004 Lyon, France, Email: kelmajri@gmail.com
}

\section{Mini Review}

There are many mentioned factors contribute to the outcome after ACL reconstruction. Braiding the strands [1], saving the ACL remnant [2], tibial tunnel independent technique or classical transtibial technique [3], bone tendon or bone tendon bone, single bundle or double bundle or double bundle double tunnel, immobilization period, knee flexion angle during immobilization, early or delayed rehabilitation and using of biological healing promotion are among them. The native ACL has no tunnel; it's inserted on the osteochondral tissue of the tibia and femur. The $3 \mathrm{D}$ orientation of the native ACL is mandatory to perform its function. The reconstructed ACL (ACL graft) is placed in position using tunnels. There is no consensus about the technique which yields anatomic placement.

The deviation of the femoral and/or tibial insertion of the ACL to one direction (anteriorly, posteriorly, medially, laterally) postoperatively will certainly change the $3 \mathrm{D}$ orientation of the ACL and affect its physiometry and hence its function. The most important part of the tunnel is the entry point of the graft into both tibial and femoral tunnels because it will be the future insertion of the reconstructed ACL. Studies on animal models show that the weak link during the early healing stage of the graft at its tunnel entrance site leading to a critical decrease in mechanical properties of the graft. The primary site of weakness during the early postoperative period is the tendon-bone interface, particularly while the tendon attaches to the bone within the intraarticular environment $[4,5]$.

The weakness of the graft can be attributed to the dilatation of the tunnel as a part of its healing process during the healing period. There are two parts of the graft, one inside the tunnel (intra-osseous) and the other outside the tunnel (intraarticular). From the Theoretical point of view: the tension between these two parts of the graft converted into compression force on the osteochondral tissue at tunnel entrance leading to erosin of the osteochondral tissues at the entry point of the graft , the new insertion will be moved toward the direction of the maximum strain at the tunnel entrance. At the tunnel entrances and during the early healing period the maximum mechanical strain (tension force) of the graft, at certain knee flexion angle, is received by the osteochondral tissues as a (compression force) on one side of the tunnel entrances according to the direction of the angle between the intra-articular and intra-osseous parts of the graft.

The mechanical strain leads to the erosion of the entry point boundary and deviation of the new insertion of the graft toward the direction of the strain and hence modifying the ultimate position of the insertion of the new ACL the weakness of the graft. The new ACL get loosen and accordingly the laxity and decrease of the mechanical properties of the graft can be attributed to this deviation (Figure 1).

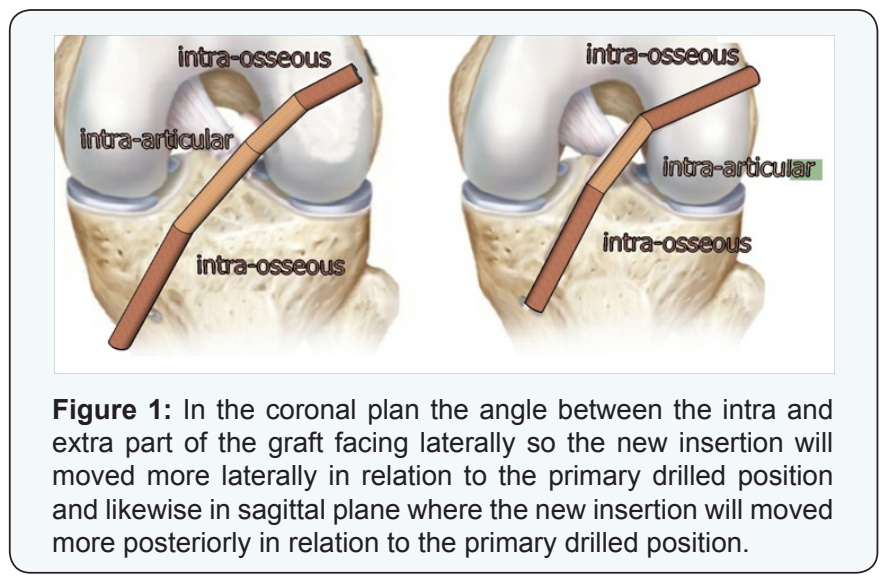

Straightening the intra-osseous (tibial and femoral) and intra-articular parts of each bundle of the graft eliminating the strain between the graft tissue and the osteochondral tissue at the tunnel entrances. The Double bundle Double Tunnel ACL Reconstruction Technique is more convincing theoretically than the single tunnel techniques and can be accomplished using the Trans-tibial tunnel drilling technique [2] in a way that eliminate the angle between the intra osseous and extra osseous parts of the graft at the tunnel entry point in sagittal and coronal planes . To create the tunnels to fulfil the above mentioned conditions, 
a modification of transtibial technique, a conception of an aimer, can be suggested (Figure 2).

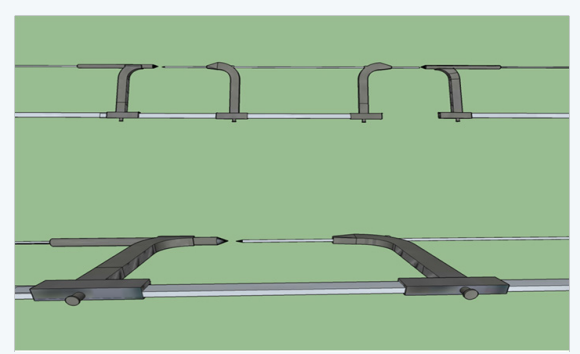

Figure 2: Suggested conception of a tunnel aimer that keeps the femoral and tibial tunnel in one axis.All four movable aimers slide on metallic band to keep all aimers in one line and insure that the guide wires pass from tibia to femur or from femur to tibia in one line.

\section{References}

1. Xu Y, Fang Y (2009) Histological and biomechanical studies of interstrand healing in fourstrand autograft anterior cruciate ligament reconstruction in a rabbit model ,Knee Surgery, Sports Traumatology, Arthroscopy 17(7): 770-777.Histological and biomechanical studies of inter-strand healing in four-strand autograft anterior cruciate ligament reconstruction in a rabbit model

2. Junkin D J, Johnson DL (2008) ACL Tibial Remnant, To Save or Not, ORTHOPEDICS 31(20:154-159.

3. Abebe ES, Moorman CT, Dziedzic TS, Spritzer CE, Cothran RL Taylor DC, et al. (2009) Femoral Tunnel Placement during Anterior Cruciate Ligament Reconstruction. An In Vivo Imaging Analysis Comparing Transtibial and 2-Incision Tibial Tunnel-Independent Techniques. Am J Sports Med 37(10):1904-1911.

4. Annual Meeting of The Orthopaedic Research Society, Anaheim, California, 1999.

5. Dargel J, Schmidt-Wiethoff R, Fischer S, Mader K, Koebke J, et al. (2009) Femoral bone tunnel placement using the transtibial tunnel or the anteromedial portal in ACL reconstruction: a radiographic evaluation Revue. Knee Surg Sports Traumatol Arthrosc 17(3): 220-227.

Your next submission with JuniperPublishers will reach you the below assets

- Quality Editorial service

- Swift Peer Review

- Reprints availability

- E-prints Service

- Manuscript Podcast for convenient understanding

- Global attainment for your research

- Manuscript accessibility in different formats ( Pdf, E-pub, Full Text, A udio)

- Unceasing customer service

Track the below URL for one-step submission https://juniperpublishers.com/online-submission.php 